\title{
The Normative Framework of the African Human Rights Regime on the Rights of Minorities
}

Beza Dessalegn*

\begin{abstract}
Minority issues in Africa have surfaced in various dimensions affecting the socio-political landscape of the continent. The protection of minorities is without doubt crucial to securing sustainable peace, economic development as well as protection and enforcement of human rights. Even though domestic mechanisms of accommodating ethnic diversity play a decisive role in the protection of minorities, the African human rights regime is also important in the protection of minorities. The African Bill of Rights embodies numerous innovative provisions which can lend support to the various minorities in Africa. The ground-breaking decisions by the African Commission also add to the existing normative discourse on minorities, especially, those dealing with peoples' rights. However, there is still much to be desired for in extending normative and jurisprudential exercises to reach out to minority issues of all sorts.
\end{abstract}

\section{Key words}

Minority Rights, African Bill of Rights, Ethnic diversity, Peoples' right, Africa

DOI http://dx.doi.org/10.4314/mlr.v8i2.8

\section{Introduction}

African states are among the most diversely populated countries in the world, and their people are markedly partitioned along linguistic, cultural, ethnic, and religious cleavages. This rich ethnic diversity of the continent

\footnotetext{
* Lecturer at Hawassa University, College of Law and Governance, School of Law.
} The author can be reached at bezadesy@yahoo.com 
has, however, brought more curse than blessings and extra trouble than tranquility. ${ }^{1}$ Even though diversity in itself is not a root cause of minority problems, the inability to manage diversity might lead to the destabilization of states. The plethora of minority issues in Africa characteristically epitomized itself in the post-independence era where conflicts as a result of minority issues ravaged the continent. ${ }^{2}$

The nature of minority issues is generally context specific, although they can have a common thread that ties all the quandaries altogether. ${ }^{3}$ The subject matter of minority issues in Africa within the context of the continent's regime of human rights, however, is of a notion which received relatively little attention although it is one of the root causes of conflict in Africa. ${ }^{4}$ It is against this conception that this comment briefly addresses the issue of minorities under the African human rights regime.

The African human rights regime profoundly rests upon the African Charter on Human and Peoples' Rights (the Charter), ${ }^{5}$ the African Charter on the Rights and Welfare of the Child (ACRWC) ${ }^{6}$ and the Protocol to the African Charter on Human and Peoples' Rights on the Rights of Women in Africa. ${ }^{7}$ These instruments constitute the African Bill of Rights. Particularly, the Charter, which recognizes peoples' rights, provides for an intrinsic link between civil and political, economic, social and cultural and collective rights.

This comment addresses two interrelated concerns. The first concern relates to the nature and content of the problems that minorities face in Africa. In this regard, minority issues are addressed as part of the challenges

\footnotetext{
${ }^{1}$ Solomon A. Dersso, "The Protection of Minorities under the African Charter: Opportunities and Challenges, paper presented at the conference on 'Organization of Justice and Protection of Fundamental Rights in South Africa and the EU' organized by UNISA and center for European Constitutional Law held in Johannesburg on 22-23 February, 1 (2007).

${ }^{2} \mathrm{Id}, 2$.

${ }^{3}$ Solomon A. Dersso, Introduction, in Solomon Dersso (ed.), Perspectives on the Rights of Minorities and Indigenous Peoples in Africa, 3 (2010).

${ }^{4}$ Solomon A. Dersso (2012), 'The African Human Rights System and the issue of Minorities in Africa', 20 African Journal of International and Comparative Law 1, 42

${ }^{5}$ African (Banjul) Charter on Human and Peoples' Rights (Adopted 27 June 1981, OAU Doc. CAB/LEG/67/3 rev. 5, 21 I.L.M. 58 (1982), entered into force 21 October 1986)

${ }^{6}$ African Charter on the Rights and Welfare of the Child OAU Doc. CAB/LEG/24.9/49 (1990), entered into force Nov. 29, 1999.

${ }^{7}$ Protocol to the African Charter on Human and Peoples' Rights on the Rights of Women in Africa, adopted in Maputo, Mozambique on 11 July 2003 and entered into force on 25 November 2005.
} 
to human rights protection. As a prelude to this discussion, the comment deals with the issue in light of a general overview of minorities in Africa. Second, having articulated the problems of minorities, it addresses these issues within the African human rights legal regime. In so doing, it looks into the rights of minorities in the African Bill of Rights and particularly the African Charter on Human and Peoples' Rights.

\section{Perspectives on Issues of Minorities in Africa}

In most African states, one can hardly find a single majority group, accounting for more than half of the total population size of a given state. Many of them are inhabited by several different groups, each comprising less than half of the total population. Be that as it may, there are a range of differences amongst the constituting groups in terms of a separate ethnic identity and power relations.

As colonialism markedly affected the political, social as well as the economic history of the African continent, the vestiges of minority issues in Africa are also marked by it. In such light, the subsequent two sub-sections discuss the varying perspectives of issues of minorities in Africa with the focal point of colonialism.

\subsection{The Colonial African State}

Minority issues in the context of Africa are highly associated with the vestiges of colonialism. The advent of colonialism in the continent created several new minority groups and exposed pre-colonial minority groups to new and intractable challenges through efforts to foster and facilitate the development of the colonial economic enterprise. ${ }^{8}$

Ethnic diversity is not something which was unique to colonial Africa. Such diversity existed even in the pre-colonial period. ${ }^{9}$ Some African countries are, however, more diverse than others. For instance, Nigeria is composed of more than 250 ethnic groups. ${ }^{10}$ Nonetheless, the issues of minorities vary from continent to continent, country to country and from one group to the other. In this context, the issue of minorities in Africa in most circumstances is a result of the post-colonial state outcome. The diversity is

\footnotetext{
${ }^{8}$ Kwadwo Appiagyei-Atua (2012), "Minority Rights, Democracy and Development: The African Experience", 12 African Human Rights Law Journal 1, 73-74.

${ }^{9}$ MW Mutua (1995), “The Banjul Charter and the African Cultural Fingerprint: An Evaluation of the Language of Duties", 35 Virginia J. Int. L., 339-347.

${ }^{10}$ World Directory of Minorities and Indigenous peoples, Available at $<$ http://www.minorityrights.org/directory $>$ (accessed 28 October 2013).
} 
not only attributable to colonialism, because the setting was widespread only for a certain period in the history of African states and Ethiopia has more than 80 ethnic identities even if it has never been colonized other than Mussolini's period of occupation during the Second World War.

The issue of colonialism in relation to ethnic diversity is particularly relevant because it has entirely transformed the boundaries of many African states. Europeans infamously scrambled over the continent, only on the basis of consensus between themselves and simple geometrical lines. ${ }^{11}$ Such undertakings asymmetrically amalgamated ethnic groups of unequal numeric, economic and socio-political status quo into a single political system. While some integrated into this system pretty well others did not, thereby leading to their relegation and marginalization. The advent of colonialism henceforth led to the emergence of new patterns of relations amongst these diversified ethnic groups. ${ }^{12}$ Colonialism completed the task of creating dominant and recessive ethnic cleavages through a set of complex procedures.

As Appiagyei-Atua rightly notes, the policy of divide and rule by the colonial powers elevated some ethnic communities considering them as 'civilized' groups and denigrating others to be looked down by their counterparts. Those who wanted to lead a lifestyle of subsistence were considered as unproductive and those engaged in sedentary life were regarded as the economic stumbling blocks; locals residing over mineral resources were marginalized so that they would opt to relinquish control over the area; and some were even driven off their lands in favor of settler colonialists, and in effect, they were left with the fate of living as 'reserve residents' and 'squatters'. 13

The making of the African state by the colonial masters resulted in the conglomeration of large number of culturally divergent, socio-politically and numerically unequal ethno-cultural communities into a singular political unit. In settings of such diversity, the political incorporation of the various ethno-cultural communities was not on equal and equitable terms. As a result, ethnic self-consciousness and rivalry between those well integrated into the colonial machinery and the relegated ones nurtured and reinforced cleavages between groups and a lasting pattern of tension between the

${ }^{11}$ See generally, I. Brownlie (1979), African Boundaries: Legal and Diplomatic Encyclopedia.

${ }^{12}$ B. Nwabuezw (2004), Constitutional Democracy in Africa, Vol. 5, 295-99.

${ }^{13}$ Appiagyei-Atua, supra note 8, p. 74-76. 
communities was entrenched. ${ }^{14}$ The colonial fiat accentuated its grip on subjects by running a scheme of unequal distribution of economic advantages, intensifying historical, cultural and socio-political differences among groups, as well as skewed education and employment opportunities. ${ }^{15}$

\subsection{The Post-Colonial African State}

The African continent is unique in its breadth of diversity. Ethnicity is more important to Africans than it is to individuals elsewhere. In much of Africa, ethnicity is the hub around which life revolves. ${ }^{16}$ Despite such diversity, many African states were not vigilant enough to contain various demands of their ethnic communities. As a result, many post-colonial African states were immediately driven into political and socio-economic unrest little after getting rid of colonialism. Instances, in Liberia, Nigeria, Sudan, Uganda and Burundi demonstrated ethnic tensions and demands premised on it. ${ }^{17}$ Alemante points out two areas of concern for such waves of ethnic unrest. The first relates to the claim by ethnic groups for non-discrimination and equal treatment for their members and the second concern, involves radical claims by the same for preserving their cultural identity and linguistic equality, to the extent of demanding political autonomy. ${ }^{18}$

Despite such claims, many African states after achieving independence started to view ethnic diversity as a burden rather than a means of successful nation building. This attitude of African states was further consolidated as they adopted liberal constitutionalism cherishing only individual rights. ${ }^{19}$ Such wave of liberal constitutionalism considered ethnicity as a private matter, lending a blind eye to the particular ethnic heterogeneity and identity of many African states. ${ }^{20}$ Henceforth, minority groups were left out and marginalized.

In many post-colonial African states a particular ethnic group is (or particular ethnic groups are) dominant over the others or this is highly

\footnotetext{
${ }^{14}$ Alemante G Selassie, "Ethnic Identity and Constitutional Design for Africa", 29 Standford J Int Law, 12-15 (1992-93).

${ }^{15}$ D Rotchild (1998), "Reconfiguring State-Ethnic Relations in Africa: Liberalization and the Search for New Routines of interaction”, in P Lewis (ed.) Africa: Dilemmas of Development and Change, 215.

${ }^{16}$ Alemante, supra note 14, p. 12.

${ }^{17}$ Ibid.

${ }^{18} \mathrm{Id}, 13$.

${ }^{19}$ Filip Reyntjens (1988), Authoritarianism for Francophone Africa from the Colonial to the Post-colonial State, 59-75.

${ }^{20}$ Alemante, supra note 14, p. 14-17.
} 
associated with public institutions. ${ }^{21}$ In this regard, the nature and the relationship between the dominant group/s and minorities take up two forms: those with a single large and politically dominant group and those with large but politically contending groups. ${ }^{22}$ Having such an impetus, the relationship between majorities and minorities in many African countries is best characterized as lacking impartial institutions and having a dominant government as well as a rivalry between contending ethnic groups for the control of the state machinery. ${ }^{23}$

However, as many African states were apprehensive of the sustenance of ethnic loyalties after independence, they ignored various ethnic community demands as they thought such would prove divisive and seriously threaten the viability of their fledging states. ${ }^{24}$ Consequently, the notions of unity accompanied by assimilation of ethnic communities within the post-colonial artificial border became the task of many states. ${ }^{25}$ However, this was done at the expense of denigrating the civil, political, linguistic, cultural and economic rights of the various resident ethno-linguistic communities in Africa.

Most importantly, apart from the need to have political influence in the government, the nature of minority issues in Africa involved the need to have access to resources and inclusion in the socio-economic framework of the state on fair and equitable terms with others. However, lacking agreement on such requisites, minorities are at a never ending battle with the state (the dominant/majority group) for a share of political power, equitable economic and wealth distribution and accommodating socio-economic structures.

It is with this background of minority issues in Africa that the subsequent section briefly examines the African human rights legal regime in the context of lending adequate fortification for minority tribulations.

${ }^{21}$ Donlad L. Horowitz (1985), Ethnic Groups in Conflict, (University of California Press) 193-194.

${ }^{22}$ Solomon A Dersso (2010), Taking Ethno-Cultural Diversity Seriously in Constitutional Design: Towards an Adequate Framework for Addressing the Issue of Minorities in Africa, PhD Dissertation, available at $<$ http://wiredspace.wits.ac.za/bitstream/handle/10539/7689/Edited\%20revised\%20for $\% 20$ final\%201.pdf? sequence=1 $>44$ (accessed on 26 September 2013).

${ }^{23}$ Id., 45.

${ }^{24}$ S.K.B. Asante (1969), "Nation building and Human Rights in Emergent African Nations”, 2 Cornell Int'l L.J. 72, 12.

${ }^{25}$ Id., 83-84. 


\section{Legal Framework of the African Human Rights Regime on the Normative Protection of Minority Rights}

As Alston and Steiner state, the African human rights system is the newest, least developed or effective, however, the most distinctive and controversial of the regional human right regimes in existence. ${ }^{26}$ This system profoundly rests on the African Charter, and is also supplemented by the African Charter on the Rights and Welfare of the Child and the Protocol to the African Charter on Human and Peoples' Rights on the Rights of Women in Africa. This section henceforth is an attempt to discuss the protection envisaged by these instruments constituting the African Bill of Rights in the context of minorities. However, the discussions are largely limited to normative guarantees stipulated in these documents.

\subsection{The African Charter on the protection of minorities}

The African Charter is applauded for its inclusion of all three generations of human rights in a single document having equal legal validity as well as enforceability. ${ }^{27}$ In particular, its inclusion of the largely controversial peoples' rights adds to its peculiarity and in reaching out to the needs of African societies to group based demands, at least, in its normative content.

The African Charter does not specifically refer to minorities as a legal category of people to protect. From this stand point, it could be argued that the human rights which can be claimed by people belonging to minorities in Africa do not differ from those embodied in other international instruments. However, as will be discussed in the subsequent subsections, with particular rights in focus, the unique normative content of the Charter containing both individual and collective rights enables the extension of such rights to minorities as well.

\section{a) Equality and Non-discrimination}

One of the demands of minorities in Africa is equal treatment of their members and the prohibition of discrimination. From this vantage point, the provisions of the Charter articles 2, 3 and 19 contain guarantees by which

\footnotetext{
${ }^{26}$ Alston and Steiner (2007), International Human Rights in Context, (Oxford University Press), 689.

${ }^{27}$ Joa Oloka-Onyango, "Reinforcing Marginalized Rights in an Age of Globalization: International Mechanism, Non-State Actors, and the Struggle for Peoples' Rights In Africa”, 18 American University International Law Review 4, 851-857, (2002-2003).
} 
these can be ensured at the individual or group level. In particular, article 2 ensures the right of every individual to the enjoyment of the rights and freedoms recognized and guaranteed in the Charter without distinction of any kind such as race, ethnic group, color, sex, language, religion, political or any other opinion, national and social origin, fortune, birth or other status. $^{28}$

As Kristin Hernand argues, since the African Charter codifies the three generation of human rights altogether, it is possible to maintain that it applies to all areas of life including minorities. ${ }^{29}$ Kristin further elaborates the bearing of article 19 of the Charter on the issue of equality, which states that, "all peoples shall be equal and that nothing shall justify the domination of a people by another" ${ }^{30}$ However, she stresses on the need to clarify the relationship that exists between articles 2 and 19. Such is the need for the African Commission to clarify the relationship between individual rights and group rights, and how violations of individual rights can be translated into violation of a group right. ${ }^{31}$

In a similar contention, Solomon Ayele maintains that the provision should be cogently interpreted with articles 20 of the Charter, 26 of the ICCPR and the provisions of the ICERD. He argues that the provision imposes obligations on public authorities not to discriminate against members of minority groups on account of their membership to a minority group and also to take necessary measures to correct the conditions that impair or diminish the enjoyment of rights by members of minority groups on an equal basis with other members of society. ${ }^{32}$ Such interpretation would undoubtedly extend the fortification of the charter to minority groups with a move to address problems of discrimination encountered by them.

\footnotetext{
${ }^{28}$ Article 2 of the African Charter.

${ }^{29}$ Kristin Hernard (2010), "The Right to Equality and Non-Discrimination and the Protection of Minorities in Africa", in Solomon Dersso (ed.), Perspectives on the Rights of Minorities and Indigenous Peoples in Africa, 242.

${ }^{30}$ Article 19 of the Charter.

${ }^{31}$ Ibid, Kristin Hernard further elaborates on the rich jurisprudence the South African Constitutional Court has offered on the Pillay case, where she argues that the insights could provide a favorable ground for the African Commission in future cases involving discrimination on minorities.

${ }^{32}$ Solomon, Issue of Minorities in Africa, supra note 4, p.44. See also General Comment No. 18 of the UN Human Rights Committee.
} 


\section{b) Freedom of expression and association}

Both the right to association and expression are at the heart of minorities to profess their group based demands. Articles 9 and 10 of the charter in this regard provide for the right to freedom of expression and association, respectively. ${ }^{33}$ Even though both rights in the charter are coined with the tone of individual rights, it is obvious that they apply to individuals who belong to minorities if they are denied of their right to express themselves or associate along with their minority community.

\section{c) The right to political participation}

The concept of political participation, as part of minority rights, is premised on two major arguments. The first premise is that, the right to political participation and the prevention of discrimination on minorities cannot be effectively ensured, unless the minority itself is actively partaking in the political decision making process, which govern the protection of its rights. ${ }^{34}$ Secondly, minorities run the risk of being excluded from the political system without special protective measures; especially in countries with mobilized ethnic nationalism majorities (and minorities) if certain minorities are unlikely to vote for parties or candidates other than their own ethnic groups. $^{35}$

Article 13 The African Charter contextually provides for the right to freely participate in the government. ${ }^{36}$ Solomon Ayele notes that, the wordings of article 13 should be understood along with articles 19 and 20 of the Charter. He states such understanding should be taken as justifying alternative governance and policy approaches that guarantee representation and equal participation by different sections of society, and hence as providing a framework to address minority conflicts arising from demands for equal participation and representation as well as a share in the economic resources of the country. ${ }^{37}$

\section{d) Socio-economic rights}

Socio-economic rights, which are classically categorized under second generation rights, require the state to take positive measures by utilizing

\footnotetext{
${ }^{33}$ Articles 9 and 10 of the African Charter.

${ }^{34}$ Florian Bieber, Balancing Political Participation and Minority Rights: The Experience of the former Yugoslavia, available at $<$ www.netrouz.com/filedownload/florian/pdf $>$ (accessed on December 28, 2008).

${ }^{35}$ Ibid.

${ }^{36}$ Article 13 of the African Charter.

${ }^{37}$ Solomon, Issue of Minorities in Africa, supra note 4, p. 45.
} 
available resources to ensure that social and economic inequities are balanced and rectified upon. ${ }^{38}$ In a move directed at codifying these rights, the African Charter has recognized rights such as the right to property, the right to work, the right to health, the right to education as well as the right to take part in the cultural life of one's community, and the right to protection of the family under articles 14-18 of the Charter. ${ }^{39}$

Although these rights are framed as individual rights, individuals belonging to minority groups cannot be denied of their socio-economic rights. One of the plights of minorities in Africa is their marginalization with respect to access to resources and their economic relegation. The African Commission is thus expected to expound the jurisprudence of the socioeconomic rights as applying to the specific quandaries of minorities. ${ }^{40}$

\section{e) Collective rights}

The African Charter provides for peoples' rights without clearly delimiting either the subject or beneficiary of the rights and the nature of the content of the rights. ${ }^{41}$ The Charter has, however, guaranteed a number of collective rights, and it is the only international human right instrument that provides fortification for peoples' rights.

The Charter reaffirms the right to self determination which has gained recognition in other legally binding international human right instruments, and it guarantees the right to existence, the right to development, the right to national and international peace and the right to environment. ${ }^{42}$ Nonetheless, the ambiguity of the term 'peoples' as applied in the African Charter casts doubt on whether such fortification could be extended to minority groups as well. ${ }^{43}$ Recent trends in the African Commission imply that the use of the term people also extends to minority groups thereby making them beneficiaries to peoples' rights stipulated under the Charter. ${ }^{44}$

\footnotetext{
${ }^{38}$ See For Example Sisay Alemahu Yeshanew (2011), The Justiciability of Economic, Social and Cultural Rights in the African Regional Human Rights System, Åbo Akad.

${ }^{39}$ See Articles 14-18 of the African Charter.

${ }^{40}$ Solomon, Issue of Minorities in Africa, supra note 4, p. 46-47.

${ }^{41}$ Solomon A. Dersso (2006), "The Jurisprudence of the African Commission on Human and Peoples' Rights with Respect to Peoples' Rights", 6 African Human Rights Law Journal 2, 360.

${ }^{42}$ See articles 20, 19, 20, 22, 23 and 24 of the African Charter respectively.

${ }^{43}$ See Generally, Richard N. Kiwanuka (1988), "The Meaning of People in the African Charter on Human and Peoples' Rights", 82 American Journal of International Law.

${ }^{44}$ Solomon, Issue of Minorities in Africa, supra note 4, p. 48.
} 


\subsection{African Charter on the Rights and Welfare of the Child (ACRWC) and the Protocol to the African Charter on Human and Peoples' Rights on the Rights of Women in Africa on the protection of minorities}

Like the African Charter, the ACRWC was adopted with the aim of ensuring that African states recognize certain specificities relating to the protection of the child. From this standpoint, the ACRWC is an important treaty for the promotion and protection of children belonging to national minorities. In this sense, the prohibition of discrimination based on cultural identity ${ }^{45}$ and safeguarding the identity and culture of the child ${ }^{46}$ play a paramount role in providing for protection.

In the implementation of the relevant provisions of the treaty, the ACRWC empowers the African Committee of experts on the rights and Welfare of the Child to follow international and comparative law on human rights and other legal instruments adopted in the framework of the United Nations by African states. It can also draw inspiration from "African values and traditions". ${ }^{47}$ This facilitates adequate protection of the rights of children belonging to minority groups and indigenous populations or communities.

On the other hand, the Protocol to the African Charter on Human and Peoples' Rights on the Rights of Women in Africa has been drafted to accelerate the elimination of discrimination and practices harmful to women in Africa. The protocol addresses almost all aspects of women's life. However, it does not make specific mention of the concerns of women belonging to minority groups or indigenous communities. In spite of this gap, it insists on the promotion of peace through curricula and social communication in order to eradicate elements in traditional and cultural beliefs, practices and stereotypes which legitimize and exacerbate the persistence thereof and tolerance of violence against women, ${ }^{48}$ the protection of women facing harmful practices or any other forms of violence, abuse, and intolerance, ${ }^{49}$ the protection of women in armed conflicts, ${ }^{50}$ and women's rights to a healthy and sustainable environment. ${ }^{51}$ If properly

\footnotetext{
${ }^{45}$ See Articles 3 and 26, paras. 2-3 of ACRWC.

${ }^{46}$ See Articles 9 paras 1 and 3; 11, para. 2 (b)-(d), (g); 12; 13 paras 1 and 2; 17, para 2

(ii); 21 paras 1 and $2 ; 23$ para 3; 25 para 3 of ACRWC.

47 Article 46 of the ACRWC.

${ }^{48}$ Article 4 para. 2 (d) of the Protocol.

${ }^{49}$ Article 5 of the Protocol.

${ }^{50}$ Article 11 of the Protocol.

${ }^{51}$ Article 18 of the Protocol.
} 
expounded, these provisions can lend support to women belonging to minority groups in many African states. Nevertheless, the task of developing such jurisprudence rests on the organs that interpret both instruments.

\section{Progress on issues of Minorities in Africa: Overview}

After independence, many African countries advocated for the sanctity of colonial borders based on the principle of utti possidetis. In so doing, they repressed various ethno-linguistic communities to avoid the recognition of groups as minorities within their territories as they feared it might lead to the emergence of nationalistic movements, eventually leading to secession and the breakup of states. ${ }^{52}$ However, the population of many African states remained multi-ethnic, multi-linguistic, and multi-religious without a clear majority. ${ }^{53}$

Conversely, contemporary minority concerns in Africa still markedly differ, for example, from classical European societies. In the African scenario, it would be a simple fallacy to apply Capitorti's distinctive features of minorities to categorize a certain population as such. The question of dominance is far from being evident in several African states, as political dominance tends to (but does not necessarily) coincide with economic, social and/or cultural dominance. Furthermore, while several political parties are formed along ethnic lines, there are constant shifts in alliances and thus political power..$^{54}$

Another important area of departure regarding minority issues in Africa relates to the subject of the preservation of culture and traditions. They resonate along with the mode of economic survival and development of the group. ${ }^{55}$ Even though the ethnic factor of minority issues in Africa is the immediate cause for conflicts, it is accompanied by factors like access to resources and control over the state machinery. ${ }^{56}$

Minority issues in Africa are also highly interwoven with the type of nation building strategy adopted by many African states after decolonization. The notion of liberal democracy swept many African states after independence. Similarly, nation building in the post colonial Africa centered on the liberal ideas by according primacy to individual rights. Henceforth,

\footnotetext{
${ }^{52}$ Henrard, supra note 29, p. 238.

${ }^{53}$ S. Slimane (2003), Minority Rights Group Briefing, Recognizing Minorities in Africa, London: MRG 1.

${ }^{54}$ Henrard, supra note 29, p. 238.

${ }_{55}$ Appiagyei-Atua, supra note 8, p. 79.

${ }^{56}$ Ibid.
} 
ethnicity as a source of collective claims was considered radical, if not unorthodox. ${ }^{57}$ However, this juxtaposition failed to bring sustainable peace in many African states. As it was premised on the simple cherishment of individual rights at the expense of minority denigration, it failed to meet its target of nation building on equitable terms. ${ }^{58}$ Contemporary constitutional designs in Ethiopia, Kenya and Sudan tend to suggest that African countries are somehow doing away with the old stubborn idea of liberal constitutionalism.

The following section analyzes the progress made in the context of minorities in Africa by looking into some decisions rendered by the African Commission. In doing so, it highlights the jurisprudence of the Commission as it applies to minorities.

\section{The Jurisprudence of the African Commission}

The supervisory role of the African Commission is very important, especially, in its interpretation of the term 'people' in relation to groups that could qualify as 'minorities' under international law and particularly as applied to the African Charter. In ascribing meaning to the term 'peoples', Solomon Ayele contends that it could refer to five different situations: i.e, peoples subject to colonial or alien domination, population of a state as a whole, people of Africa in general, states themselves as a boost to their sovereign rights, and the highly controversial understanding by which peoples refer to distinct communities constituting the state. ${ }^{59}$

The African Commissions' case law on peoples' rights shows that substate groups within a certain state could be considered as people within the meaning of the African Charter. Cases dealt by the Commission in connection with the Ogoni in Nigeria, ${ }^{60}$ the black Mauritanians in Mauritania, ${ }^{61}$ the population of Katanga in Zaire ${ }^{62}$ and legal resources foundation v. Zambia ${ }^{63}$ substantiate this interpretation. ${ }^{64}$

\footnotetext{
${ }^{57}$ Alemante, supra note 14, p. 19.

${ }^{58}$ Appiagyei-Atua, supra note 8, p. 82- 86.

${ }^{59}$ Solomon, The Jurisprudence of the African Commission, supra note 41, p. 360-364.

${ }^{60}$ Social and Economic Rights Action Center (SERAC) \& Another v Nigeria (2001) AHRLR 60 (ACHPR 2001).

${ }^{61}$ Malawi Association \& others v Mauritania (2000) AHRLR 149 (ACHPR 2000).

${ }^{62}$ Katangese Peoples'v Zaire (2000) AHRLR 72 (ACHPR 1995).

${ }^{63}$ Legal Resources Foundation v Zambia (2001) AHRLR 84 (ACHPR 2001).

${ }^{64}$ For a detailed account of these cases See, Solomon, The Jurisprudence of the African Commission, supra note 41 .
} 
In the Katangese case, the African Commission impliedly recognized the various inhabitants of the Katanga province in Zaire as people, however, rejecting their quest to external self determination. ${ }^{65}$ The term people can thus be construed to mean a section of the population of a state. ${ }^{66}$ In the case of black Mauritanians, a communication was brought to the Commission alleging a series of human rights violations committed by the ruling Arabs against black Mauritanians. The Commission adhered to the recognition of people in its entirety as a population of the state. It stated that the violation against black Mauritanians in Mauritania is against the stipulations of the African Charter ${ }^{67}$ In the case of the Ogoni in Nigeria, the Commission applied the term people to apply to a distinct community. It held that the Nigerian government and shell are accountable for violations of civil and political, socio-economic as well as collective rights of the Ogoni people, a distinct ethnic group living in Ogoni land. ${ }^{68}$ Finally, in the legal resources foundation case the Commission gave a definition to the ethnic dimension of the term 'people'. 69

The jurisprudential exercise by the African Commission in expounding the understanding of the term people has gone to the extent of recognizing distinct communities within a certain state to qualify as people within the meaning of the African Charter. However, the Commission did not go to the extent of delimiting the right of these affected communities, and it thus remains ambiguous whether such recognition of people extends to the existing various types of minorities in Africa.

With regard to indigenous peoples, they are classified as both minority and indigenous. Yet, indigenous peoples' rights as developed by intergovernmental organizations are far more extensive, stronger and detailed than minority rights. ${ }^{70}$ In an ingenious decision regarding indigenous peoples, the African Commission on Human and Peoples Rights accorded special and separate recognition to the existence of indigenous peoples in Africa. The Commission clarified that, in Africa, 'indigenous population' does not refer to 'first inhabitants' in reference to aboriginality as opposed to

\footnotetext{
${ }^{65}$ Katangese Peoples' v Zaire, supra note 62.

${ }^{66}$ Solomon, The Jurisprudence of the African Commission, supra note 41, p. 366.

${ }^{67}$ See, Malawi Association \& others v Mauritania, supra note 61.

${ }^{68}$ See, SERAC \& Another v Nigeria, supra note 60.

${ }^{69}$ See, Legal Resources Foundation v Zambia, supra note 63.

${ }^{70}$ See, Kamrul Hossain (2008), "Status of Indigenous Peoples in International Law", 5 Miskolc Journal of International Law 1, 24.
} 
non-African communities or those that come from elsewhere. ${ }^{71}$ Pursuant to the reasoning of the Commission, the principal criterion in determining indigenous peoples in Africa is historical marginalization and isolation from mainstream politics and economic life, and spiritual or cultural attachment to land and the natural resources thereon, rather than original or first occupation. $^{72}$ The Commission pursued this interpretation in the Endorois case, and it departed from the commonly held belief that all Africans are autochthones and therefore indigenous. ${ }^{73}$

\section{Conclusion}

Minority issues in Africa have surfaced in various forms: ranging from ethnic strife, civil wars to the breaking up of states. Such frictions have adversely affected Africa's economic development, human right protection, and good governance records. The protection of minorities, henceforth, is one of the key factors in securing sustainable peace, economic development as well as protection and enforcement of human rights. Such protection of minorities should be ensured not only by domestic mechanisms of accommodating ethnic diversity, but also through the African human rights regime.

The African human rights regime under its African Bill of Rights embodies numerous innovative provisions which can lend support to the various tribulations of minorities in Africa, though not for all types of minorities. The ground-breaking decisions by the African Commission also add to the existing normative discourse on minorities, especially, those dealing with peoples' rights. However, it should be noted that there is still much to be desired for in extending normative and jurisprudential exercises to reach out to minority issues of all sorts.

${ }^{71}$ Advisory Opinion of the African Commission on Human and Peoples' Rights on the United Nations Declaration on the Rights of Indigenous peoples (2007), available at http://

$<$ www.achpr.org/english/Special\%20Mechnisms/Idigenous?Advisory\%20opinion_en g.pdf $>$ (accessed 20 September 2013).

72 See, Adem Kassie Abebe (2012), "Limitations to the Rights of Indigenous Peoples in Africa: A Model for Balancing National Interest in Development with the Rights of Indigenous Peoples?" 20 African Journal of International and Comparative Law 3, 411.

${ }^{73}$ See generally, Center for Minority Rights Development (Kenya) and Minority Rights Group International on Behalf of the Endorois Council $v$ Kenya, communication no 276/2003, ACHPR (2010). 